DIW BERLIN

Discussion

Papers

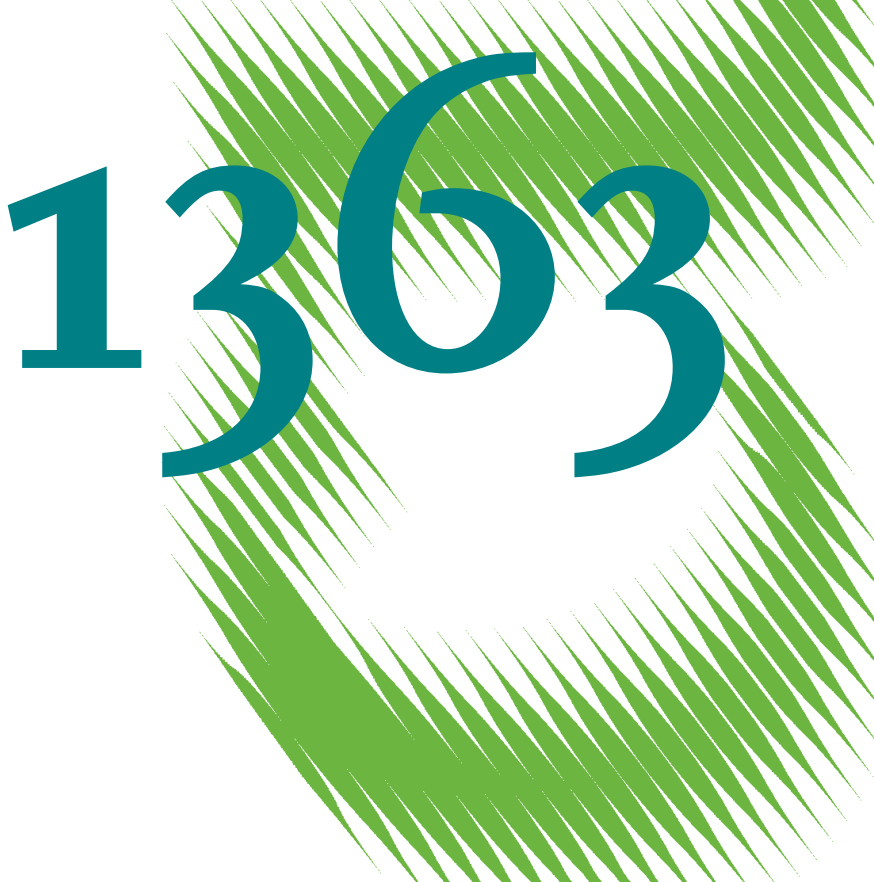

Comparison of Feed-in Tariffs and Tenders to Remunerate Solar Power Generation 
Opinions expressed in this paper are those of the author(s) and do not necessarily reflect views of the institute.

IMPRESSUM

(C) DIW Berlin, 2014

DIW Berlin

German Institute for Economic Research

Mohrenstr. 58

10117 Berlin

Tel. $+49(30) 89789-0$

Fax +49 (30) $89789-200$

http://www.diw.de

ISSN print edition $1433-0210$

ISSN electronic edition 1619-4535

Papers can be downloaded free of charge from the DIW Berlin website:

http://www.diw.de/discussionpapers

Discussion Papers of DIW Berlin are indexed in RePEc and SSRN:

http://ideas.repec.org/s/diw/diwwpp.html

http://www.ssrn.com/link/DIW-Berlin-German-Inst-Econ-Res.html 


\title{
Comparison of Feed-in Tariffs and Tenders to Remunerate \\ Solar Power Generation
}

\section{Thilo Grau*}

February 12, 2014

\begin{abstract}
This paper analyzes the trade-offs for using feed-in tariffs or tenders to remunerate different scales of solar photovoltaics (PV) projects. In recent years, European countries increasingly combined feed-in tariffs for small renewables systems with tenders for large installations. This study develops an analytic framework to quantify deployment effectiveness of responsive feed-in tariff adjustment mechanisms across project scales and to compare specific cost effectiveness factors of feed-in tariffs and tenders for PV plants with their dynamic cost trends. To assess deployment effectiveness, an analytic model is used to simulate installations and feed-in tariffs for different project sizes. Then semi-structured interviews with German and French project developers are conducted to identify additional factors to be considered for a comparison of feed-in tariffs and tenders, and to explore how different remuneration schemes impact cost of capital and transaction costs. The paper finally discusses the relative merits of feed-in tariffs and tenders.
\end{abstract}

JEL Classification: O33, Q42, Q48.

Keywords: Feed-in tariff, tender, solar photovoltaics.

\footnotetext{
* German Institute for Economic Research (DIW Berlin), Germany (e-mail: tgrau@diw.de). I am grateful to Karsten Neuhoff, Jochen Diekmann, Rolf Wüstenhagen, Katherina Grashof, Sebastian Schwenen, Matthew Tisdale, as well as participants at the Enerday conference in Dresden, Strommarkttreffen in Berlin, the IAEE European conference in Düsseldorf, and Gretchen stakeholder workshop in Berlin in 2013 for their constructive comments.
} 


\section{Introduction}

The academic literature usually differentiates two categories of policy instruments to support deployment of renewable electricity sources: price-based mechanisms, like feed-in tariffs or premiums, and quantity-based schemes, like tenders or quota systems (Menanteau et al., 2003, Butler and Neuhoff, 2008, Haas et al., 2011). Feed-in tariffs are the most common policy instrument to support renewable electricity globally, being implemented by 65 countries and 27 states / provinces, while tenders for renewables have been adopted by 33 countries in 2012 (REN21, 2012).

The combination of feed-in tariffs with tendering schemes has increased in European countries, from two countries having implemented this combination in 2005 to five countries in 2011, with more countries applying feed-in tariffs for small systems than for large installations across renewable electricity technologies, and most tendering schemes being applied for large-scale PV and biomass as well as offshore wind installations (Kitzing et al., 2012). For instance, based on its existing feed-in tariff scheme, France in 2011 included tenders for large-scale PV systems. The German Federal Ministry for Economic Affairs and Energy stated that the entire remuneration for ground-mounted PV installations shall be shifted from feed-in tariffs to tenders (BMWi, 2014). Despite the fact that several countries have introduced combined feed-in tariff and tender schemes, a thorough investigation of how to select an optimal threshold level has not been conducted so far. This leads to the research question for this paper: What are the trade-offs for using feed-in tariffs or tenders for the support of different scales of solar PV projects?

In a feed-in tariff system, investors receive a guaranteed price for renewable power generation (per $\mathrm{kWh}$ ) for a specific time period. This remuneration price is determined administratively by public authorities. There are different general ways to structure the remuneration of feed-in tariffs (Couture and Gagnon, 2010). The German Renewable Energy Sources Act (EEG) with its fixed price feed-in tariff scheme has been effective in encouraging a rapid expansion of renewable electricity. However, despite several amendments and the introduction of flexible adjustment mechanisms, the feed-in tariff system led to strong overshoots of planned annual solar photovoltaics (PV) deployment between 2010 and 2012. This presents a challenge as the regularly increasing EEG levy leads to increasing electricity prices to consumers.

By contrast, tender mechanisms use an auction to determine the required remuneration levels. There are different types of tendering schemes used in the electricity sector to remunerate renewable power generation, with the remuneration price usually being the only or the most important evaluation criterion. The auction result can determine the premium or the full remuneration level. This work focuses on the experience with tenders in countries like France, Denmark, the UK, China, India, California and Brazil. In these tendering systems, investors bid a certain price for every $\mathrm{kWh}$ of electricity produced, which they need to install the plant. The final remuneration tariff is paid for a specific time period or a given amount of full load hours. The auction for wind farms in Brazil in 2009 resulted in an impressive 44\% discount from the previous prices in the Proinfa (programme of incentives for alternative electricity sources) feed-in tariff program (Cunha et al., 2012). Moreover, tenders promise predictable deployment outcomes (as quantities are set) and control options regarding regional supply needs and network expansion. However, auctionbased schemes imply several challenges and additional transaction costs relative to feed-in tariffs, like higher risks associated with project development (as not all bids will be successful), attrition because of speculative underbidding, or risks of market concentration. Batlle et al. (2012) 
recommend that regulators should move, as soon as there is sufficient competition between generators of renewable electricity, from feed-in tariffs to auctions.

This paper analyzes both deployment effectiveness of responsive feed-in tariff adjustment schemes and specific cost effectiveness factors of feed-in tariffs and tenders with a focus on different project sizes categories for solar PV plants with their dynamic cost trends. The hypothesis is that feed-in tariff remuneration is more effective and efficient for small PV installations, while tenders may be more suitable for large-scale projects.

PV projects are usually categorized into small residential rooftop systems, mid-scale commercial systems, as well as large ground-mounted plants. Reichmuth (2011) shows that private investors account for around 40\% of new installations in Germany in 2009 and 2010, with average system sizes being concentrated between 5 and $10 \mathrm{~kW}$, which is typical for one family houses. Farmers focus their investments on systems of around $30 \mathrm{~kW}$ (large rooftops, for instance on barns), while commercial and industrial investors account for a larger share of plants with $100 \mathrm{~kW}$ and more. According to Maron et al. (2011), the ownership structure in the PV sector in Germany is dominated by private persons who account for $39 \%$ of cumulative installations, followed by farmers (21\%) and business (19\%) in 2010. Project developers, funds and banks often invest in large ground-mounted PV plants.

This work assesses the distinctive characteristics of the different project size categories, including market evolution, project durations, administrative barriers, labor requirements, and financing risks. Using a unique dataset on weekly PV installations, this paper develops an analytic model to simulate weekly PV deployment and feed-in tariff levels for various project scales under the responsive tariff adjustment mechanism in Germany, accounting for differences in project profitability and duration (based on a linear regression analysis). 21 semi-structured expert interviews with international PV project development companies lead to additional insights about different cost effectiveness dimensions, in particular cost of capital and transaction costs. Most interview partners reported on their experiences with tenders in France, followed by South Africa. Therefore, this study compares financing and transaction costs for the German and French cases in detail.

The analysis shows that large installations, with their significantly longer project development times, are more responsive to changes in system prices and policy adjustments than small systems. Model results illustrate that the flexible German feed-in tariff scheme with its frequent tariff adjustments is able to reach deployment targets more effectively for small PV systems than for large-scale plants. Tenders lead to larger financing cost for project developers, relative to feed-in tariffs, in particular because of higher costs of equity and debt, with the weighted average cost of capital converging for large projects. Moreover, tenders imply longer project development times and higher project development cost.

The structure of the paper is as follows. The next section reviews the existing responsive feed-in tariff adjustment mechanism across project scales in Germany, and the remuneration system in France as one concrete case with feed-in tariffs for small systems and tenders for large installations. The third section develops the analytic framework, containing both the deployment model as well as the cost effectiveness dimensions. The fourth section describes the data for the deployment model, assesses the differences between small and large projects, and shows the simulation results. The fifth section describes the interview sample, and shows the interview results with regard to cost of capital and transaction costs. The final section offers conclusions. 


\section{$2 \quad$ Feed-in tariffs and tenders}

This section reviews the evolution of the German PV feed-in tariff scheme with its responsive adjustment of remuneration levels across project scales, highlights challenges resulting from its current design, and introduces the governments' interest in implementing tenders for large installations. Thereafter, the paper assesses the French remuneration system as one concrete case with feed-in tariffs for small systems and tenders for large-scale plants, by describing its evolution and design, as well as the reasons for choosing the respective threshold levels.

\subsection{Flexible feed-in tariff adjustment across project sizes: The German case}

The German Renewable Energy Sources Act (Erneuerbare-Energien-Gesetz, EEG) with its fixed feed-in tariffs has been successful in deploying renewable energies in Germany: Their share in electricity generation increased from 6\% in 2000, when the EEG was introduced, to 23.5\% in 2012 (BMU, 2013). Solar PV feed-in tariffs in Germany are paid for 20 years, counting from commissioning, and are not indexed to the price level. While the German government defined annual targets for the deployment of renewable energies until 2020 within its National Renewable Energy Action Plan (BRD, 2010), the latest EEG amendment (EEG, 2012) defines an annual target corridor of between $2.5 \mathrm{GW}$ and $3.5 \mathrm{GW}$ for new PV installations.

Solar PV plants showed the strongest price reductions of all renewable energy technologies, as their system prices decreased by around $66 \%$ during the last six years (BSW-Solar, 2013). However, PV installations in most cases are not yet cost competitive with conventional power generation technologies, and therefore need further remuneration. After PV feed-in tariff levels were originally reduced by annual degression rates (like for other renewable energy technologies), several shortterm degression adjustments were implemented between 2010 and 2012, due to the dynamic price evolution of PV modules. This shows the difficulty of ex-ante identifying the correct degression rate for a dynamic technology like PV.

The German government released the new version on the PV feed-in tariff adjustment mechanism in June 2012, with the law coming into force on 1 April 2012. This included a one-off tariff reduction on 1 April 2012, ranging between 20 to 29 percent for new installations. However, with regard to protection for reliance on existing law, several transitional provisions were implemented. For instance, ground-mounted installations further received the old feed-in tariff levels if the planning process had started before March 2012 and if the system was commissioned until 30 June 2012, while the commissioning time was extended until 30 September 2012 for installations on conversion areas.

Before April 2012, PV feed-in tariffs in Germany were categorized into 6 groups: rooftop systems up to $30 \mathrm{~kW}$, to $100 \mathrm{~kW}$, to $1000 \mathrm{~kW}$, larger than $1 \mathrm{MW}$, as well as ground-mounted installations on conversion areas, and other spaces (remuneration for systems on agricultural fields was stopped in July 2010). Since April 2012, feed-in tariffs for rooftop systems are categorized according to new size categories: up to $10 \mathrm{~kW}$, to $40 \mathrm{~kW}$, to $1 \mathrm{MW}$, and to $10 \mathrm{MW}$, while ground-mounted PV systems up to $10 \mathrm{MW}$ receive a uniform tariff level.

Since May 2012, PV feed-in tariffs are reduced on a monthly basis. To deliver the annual deployment corridor, degression levels depend on deployment since November 2012, are implemented on a monthly scale and adjusted every three months. To determine deployment and new feed-in tariff 
levels, the Federal Network Agency (Bundesnetzagentur) has a time period of one month. This implies a time lag between PV price reductions, corresponding deployment, and final feed-in tariff adjustment.

In recent years, the share of small-scale PV systems ( $\leq 30 \mathrm{~kW}$ ) decreased from $43 \%$ in 2009 to $23 \%$ in 2012, while the share of large-scale installations (>1MW) increased from 17\% in 2009 to $42 \%$ in 2012. This shows that a balanced market growth of different project scales may be difficult to reach with the same feed-in tariff adjustment mechanism across size categories.

The German Federal Ministry for Economic Affairs and Energy aims at quickly and fundamentally reforming the EEG until summer 2014, and states that the entire remuneration for ground-mounted PV systems will be shifted to tendering mechanisms by auctioning $400 \mathrm{MW}$ per year (BMWi, 2014).

\subsection{Feed-in tariffs for small and tenders for large systems: The French case}

In France, a feed-in tariff support scheme for PV systems was introduced in 2002 and amended several times in the years thereafter. Tariff levels for plants commissioned in 2009 ranged between 32.8 and $60.1 \mathrm{ct} / \mathrm{kWh}$ fixed for 20 years (Klein et al., 2010). In 2009, one call for tenders dedicated to overseas territories was introduced, but finally declared unsuccessful. After a boom of installations which applied for grid connection in 2009 and 2010, public authorities implemented a moratorium on feed-in tariffs, which lasted for three months.

The Charpin Trink concertation took place for three months during winter 2010/2011, gathering and interviewing all actors of the sector (Charpin and Trink, 2011). The call for tenders (appel d'offres) for PV installations larger than $100 \mathrm{~kW}$ (simplified tender) and larger than $250 \mathrm{~kW}$ was launched after the concertation in 2011, while a non-profitability feed-in tariff was published for plants larger than $100 \mathrm{~kW}$. Another call for tenders was implemented in 2013. Thus, today there are feed-in tariffs for small systems up to $100 \mathrm{~kW}$, and tenders for larger installations. One motivation to introduce tenders in France was to better control deployment volumes. Table 1 shows the current categories for the support of solar PV in France, based on MEDDE (2013), with the annual deployment target being $1000 \mathrm{MW}$.

Table 1: PV support categories in France

\begin{tabular}{|l|l|l|l|l|}
\hline \multicolumn{2}{|l|}{ Installation type } & Capacity & Support scheme & Annual target \\
\hline \multirow{4}{*}{ Rooftop } & Residential & $0-9 \mathrm{~kW}$ & Feed-in tariff, revised quarterly & $200 \mathrm{MW}$ \\
\cline { 2 - 5 } & \multirow{3}{*}{ Non-residential } & $0-100 \mathrm{~kW}$ & Feed-in tariff, revised quarterly & $200 \mathrm{MW}$ \\
\cline { 3 - 5 } & & $100-250 \mathrm{~kW}$ & Simplified tender & $120 \mathrm{MW}$ \\
\cline { 3 - 5 } & $>250 \mathrm{~kW}$ & Tender & \multirow{2}{*}{ At least $400 \mathrm{MW}$} \\
\hline Ground-mounted & $>250 \mathrm{~kW}$ & Tender & \\
\hline
\end{tabular}

The reasons for choosing the thresholds of $100 \mathrm{~kW}$ and $250 \mathrm{~kW}$ for PV tenders are explained by the French Commission for Energy Regulation (Commission de régulation de l'énergie) as follows: (i) they are one of the conclusions of the Charpin Trink concertation, (ii) considering the electric network, the $250 \mathrm{~kW}$ threshold is the limit between low voltage and medium voltage, and corresponds to a connection threshold for ERDF (Électricité Réseau Distribution France), the operator of the low and medium voltage distribution system, (iii) the feed-in tariffs described in the orders of January and August 2010 distinguished the threshold of $250 \mathrm{~kW}$, and (iv) the facilities between 100 and $250 \mathrm{~kW}$ 
correspond to non-residential roofs, the category which had exploded during the 2010 bubble, so the new mechanism was designed to control its development.

The tenders are based on a points-based criteria system, with an overall maximum score of 30 points. Table 2 shows the weighting of the relevant criteria with their individual maximum scores for the respective tenders, based on CRE (2013a) and CRE (2013b). While the actual tariff level (price) receives most points in the simplified tender, environmental impact and R\&D contribution are weighted stronger in the tender for plants larger than $250 \mathrm{~kW}$.

Table 2: Criteria system with weightings (maximum scores) in French PV tenders

\begin{tabular}{|l|c|c|c|}
\hline Criteria & Simplified tender & \multicolumn{2}{|c|}{ Tender for installations larger than 250 kW } \\
\cline { 3 - 4 } & $(100$ up to $250 \mathrm{~kW})$ & Sub categories 1a, 1b, 2 & Sub categories 3, 4, 5 \\
\hline Price (tariff level) & 20 & 12 & 12 \\
\hline $\begin{array}{l}\text { Simplified carbon } \\
\text { evaluation }\end{array}$ & 10 & & \\
\hline Environmental impact & & 10 & 10 \\
\hline $\begin{array}{l}\text { Contribution to research } \\
\text { and development }\end{array}$ & & 8 & 30 \\
\hline Total & 30 & 30 & \\
\hline
\end{tabular}

The cumulative installed PV power generation capacity in France accounted for $4.03 \mathrm{GW}$ at the end of 2012 (CGDD, 2013a). Installations larger than $250 \mathrm{~kW}$ have a market share of 44\%, while systems between 100 and $250 \mathrm{~kW}$ represent a 21\% share. New installations amounted to $1.7 \mathrm{GW}$ in 2011 and 1.1 GW in 2012. $207 \mathrm{MW}$ of new systems were installed in the first half of 2013 (73\% less in comparison to the first half of 2012) (CGDD, 2013b), with $41 \%$ of these installations belonging to the size category between 36 and $100 \mathrm{~kW}$.

\section{Method, Analytic framework}

The aim of the analytic framework developed in this section is to analyze the trade-offs for using feed-in tariffs or tenders to remunerate solar electricity generation. The underlying hypothesis is that the optimal policy scheme to support renewable energies depends on the size of investment projects. More specifically, the hypothesis is that feed-in tariff remuneration is more effective and efficient for small PV systems, while tenders could be more suitable for large-scale projects.

To investigate the research question, this study combines an analytic model based on quantitative regression analysis with qualitative case study research. The evaluation considers two policy objectives: Deployment effectiveness and cost effectiveness. The methodology used is novel in that it combines a linear regression analysis to analyze deployment effectiveness of responsive feed-in tariff mechanisms with semi-structured interviews to assess different aspects of cost effectiveness for remuneration through feed-in tariffs and tenders. The analysis was proceeded in two major steps.

First, 21 expert interviews were conducted with market professionals from international PV project developing companies based in Germany and France in 2013. An interview questionnaire (see Appendix) was developed building on insights generated through comprehensive literature review. This questionnaire served as the basis for a semi-structured discussion during the interviews. The 
questionnaire contains four parts: (i) characteristics and activities of the market experts and their companies, (ii) project development stages and process durations, (iii) project risks and probabilities of project abandonment, as well as (iv) project financing, cost of capital, and transaction costs. The interviews typically took between 20 and 60 min and were documented in interview transcripts.

Second, an analytic model was developed to quantitatively analyze deployment effectiveness (in terms of target achievement) of responsive feed-in tariff adjustment mechanisms with regard to different system size categories. This model was calibrated based on regressions of past deployment trends in Germany. The framework used by Grau (2012) for small-scale PV systems was expanded to allow for an assessment of different project sizes with their respective market characteristics, and modified with additional insights generated through the expert interviews.

\subsection{Deployment model to analyze target achievement}

Deployment effectiveness is measured in terms of reaching installations targets. A policy instrument works effectively if renewables deployment develops within a certain target corridor defined by the respective government, i.e. the optimal policy effectiveness shall correspond to supporting this deployment target corridor.

The model used to analyze deployment effectiveness for responsive feed-in tariff adjustment mechanisms is based on the factor that deployment and project profitability are positively correlated. Therefore, the methodological framework in this section is based on the basic model developed by Grau (2012). The approach considers a discrete-time economy. At the beginning of every period $t$, each investor (household, project developer, etc.) decides whether to invest in a PV project with a specific system size $s$, that would be finalized at date $t+d_{s}$, taking into account the average project duration $d_{s}$. PV installations $Y_{s, t+d}$ of system size category $s$ at time $t+d$ depend on expected profitability $\pi_{s, t+d}$ according to the function

$$
Y_{s, t+d}=\alpha * \pi_{s, t+d}-c,
$$

with parameters of responsiveness $\alpha$ and $c$. Both parameters can be determined for different time periods, to account for changing profit expectations of investors over time.

Profits of PV projects are defined as net present value (NPV):

$$
\pi_{s, t+d}=v_{s, t+d}-p_{s, t}
$$

where $p_{s, t}$ is the average system price of size category $s$ at date $t$ and $v_{s, t+d}$ is the present value of the feed-in tariff of size category $s$ at time $t+d$. Maintenance costs are relatively small and therefore neglected here.

The present value $v_{s, t}$ of the feed-in tariff is given by the equation:

$$
v_{s, t+d}=f_{s, t+d} * h * \sum_{j=0}^{n}(1+i)^{-j},
$$

where $f_{s, t}$ is the feed-in tariff of size category $s$ at date $t, h$ is the amount of full load hours per annum, $n$ is the amount of years which the feed-in tariff is paid for, and $i$ is the annual interest rate.

In the framework of this model, the responsive interactions of deployment volumes and feed-in tariff adjustments (see section 2.1) are simulated for individual project size categories. This separate 
treatment of project scales allows to clearly identify their respective impacts on deployment effectiveness of responsive feed-in tariff adjustment mechanisms.

\subsection{Expert interviews to analyze cost effectiveness}

Cost effectiveness of public support for renewable electricity can be defined as minimization of renewable electricity generation costs, or as minimization of consumer costs (del Río and Cerdá, 2014). Cost effectiveness can also be called efficiency (Mitchell et al., 2011). This paper uses semistructured expert interviews with international project development companies to explore how feedin tariffs and tenders impact two specific dimensions of cost effectiveness: cost of capital and transaction costs. Section 5.1 describes the interview sample and the relevant countries. The following sub-sections explain the methodological framework to analyze cost of capital as well as transaction costs.

\subsubsection{Cost of capital}

The cost of capital contains the cost of equity and the cost of debt. To calculate the cost of capital, the WACC (weighted average cost of capital) approach is used here.

$$
W A C C=\frac{\text { equity }}{\text { capital }} * \text { cost of equity }+\frac{\text { debt }}{\text { capital }} * \text { cost of debt } *(1-\text { corporate tax rate })
$$

The cost of equity is defined as the risk-weighted projected return which is required by the investor. The cost of debt consists of the interest rate paid by the investor. Both cost of equity and cost of debt can be modeled as a risk free rate plus a risk premium. Corporate tax levels differ across countries.

Project financing is a common mechanism for companies to finance renewable energy projects, in particular for small project developers. Large firms can also use their ability to finance projects on their balance sheet (corporate finance).

Jager de and Rathmann (2008) define six levels of risk which can affect the cost of capital for renewable energy projects: project level risk (especially during construction and operation), regulatory risk (due to changes of policies), financial and market risk (like changes in interbank offered interest rates), legal risk, (geo)political risk (sovereign risk), and force majeure risk (e.g. concerning natural catastrophes). As this paper compares feed-in tariffs and tendering schemes, and in particular policies implemented in Germany and France, the focus is on the first three risk levels, while the other levels are assumed to be similar in both neighboring countries.

Both equity investors and lenders like banks assess the associated project risks and establish corresponding financial requirements like for instance the share of equity required. By focusing on PV project developers investing in countries with feed-in tariffs, Lüthi and Wüstenhagen (2012) empirically measure the price premiums which can be attached to policy risks like administrative process duration, policy stability, or the existence of a capacity cap.

Project developers (equity investors) use different metrics to determine the desirability of potential PV projects. A common metric of project profitability is the internal rate of return (IRR), or the internal rate of return after debt is serviced. 
The internal rate of return $r$ of an investment project is the discount rate that makes the net present value (NPV) equal to zero. Thereby, the investment I is contrasted with the sum of all discounted cash flows $\mathrm{C}_{\mathrm{t}}$ at times $\mathrm{t}$ (with T periods).

$$
N P V=\sum_{t=1}^{T} \frac{C_{t}}{(1+i)^{t}}-I=0
$$

If the IRR is larger than the respective threshold, the investment will be attractive for the investor. The higher the IRR, the more desirable is the development of the project from an investor perspective.

The expert interviews in this regard focused on debt-equity ratios, cost of equity and cost of debt for different size categories, to allow for the calculation of WACC values across project scales for different countries. Finally, to enable a direct comparison of the cost of capital under feed-in tariffs and tenders, national WACC values are corrected for the yields of the respective ten year government bonds.

\subsubsection{Transaction costs}

In comparison to feed-in tariffs, tenders imply several transaction costs. Transaction costs for tendering schemes are diverse in nature. Based on the literature review, the most important transaction costs of tenders are costs for collaterals (deposits) for project developers (to avoid nondelivery), costs due to longer project development times because of the process duration of tenders, and costs incurred by bidders that subsequently fail to win in the tender.

To quantitatively analyze transaction costs, this study focuses on the additional project development time and costs necessary to participate in tenders in comparison to a feed-in tariff scheme, from the perspective of a representative investor, as they can be quantified by expert interviews. In particular, the analysis focuses on: (i) project development times, (ii) project development costs (including costs for collaterals in tenders), and (iii) costs due to the lower success rate in tenders.

To allow for a meaningful comparison of transaction costs under feed-in tariffs and tenders, the focus of this analysis is on the project development phase. This is often the most risky period of the project. From the construction phase onwards, factors like investment cost and remuneration rates could be equal under feed-in tariff and tender schemes. In tenders modules and equipment are usually only ordered as soon as the tender is won. To analyze cost for collaterals, the focus is on the point in time when the collateral is posted in the project development phase, and on the duration for which it is deposited.

\section{$4 \quad$ Quantitative evaluation of deployment effectiveness}

\subsection{Data and parameter choices for deployment model}

The regression analysis to assess the deployment effectiveness of the PV feed-in tariff adjustment mechanism in Germany is based on various data sources. This section describes the data used to calibrate the individual variables of the deployment model (see section 3.1). Moreover, the following paragraphs assess differences in market behavior of the individual project size categories, including the impact of profitability on deployment volumes and the responsiveness of investors to changes in sudden policy amendments. 


\section{Deployment, feed-in tariff adjustments, and market responsiveness}

A period $t$ corresponds to one week for the purpose of this application, as PV project durations range between 5 to 53 weeks in Germany (PVGrid, 2014). Feed-in tariff levels $f$ and corresponding degression rates for the different installation types and system sizes between January 2009 and October 2013 are based on the respective versions of the Renewable Energy Sources Act (EEG) and (BNetzA, 2013).

Installations $Y$ were aggregated for different system size categories during the time period between January 2009 and July 2013 based on system-specific data from the German Federal Network Agency for Electricity, Gas, Telecommunications, Post and Railway (Bundesnetzagentur) (BNetzA, 2013). Since January 2009, new PV installations must be registered at this agency. The Agency regularly publishes system-specific data for all installations, with date of registration, plant capacity, and locational information. Although this data does not provide information about installation types (like, for instance, residential rooftop, or ground-mounted on conversion areas), a careful assessment of policy evolution and market investment behavior in 2012 allows to derive the respective information.

Figure 1 shows weekly installations and exemplary feed-in tariff levels in 2012 for small systems up to $100 \mathrm{~kW}$ and large-scale installations. We observe a characteristic market behavior of investors: The deployment volume always strongly increased in periods prior to feed-in tariff reductions.

Figure 1: Weekly PV installations and exemplary feed-in tariff levels for different size categories in Germany in 2012
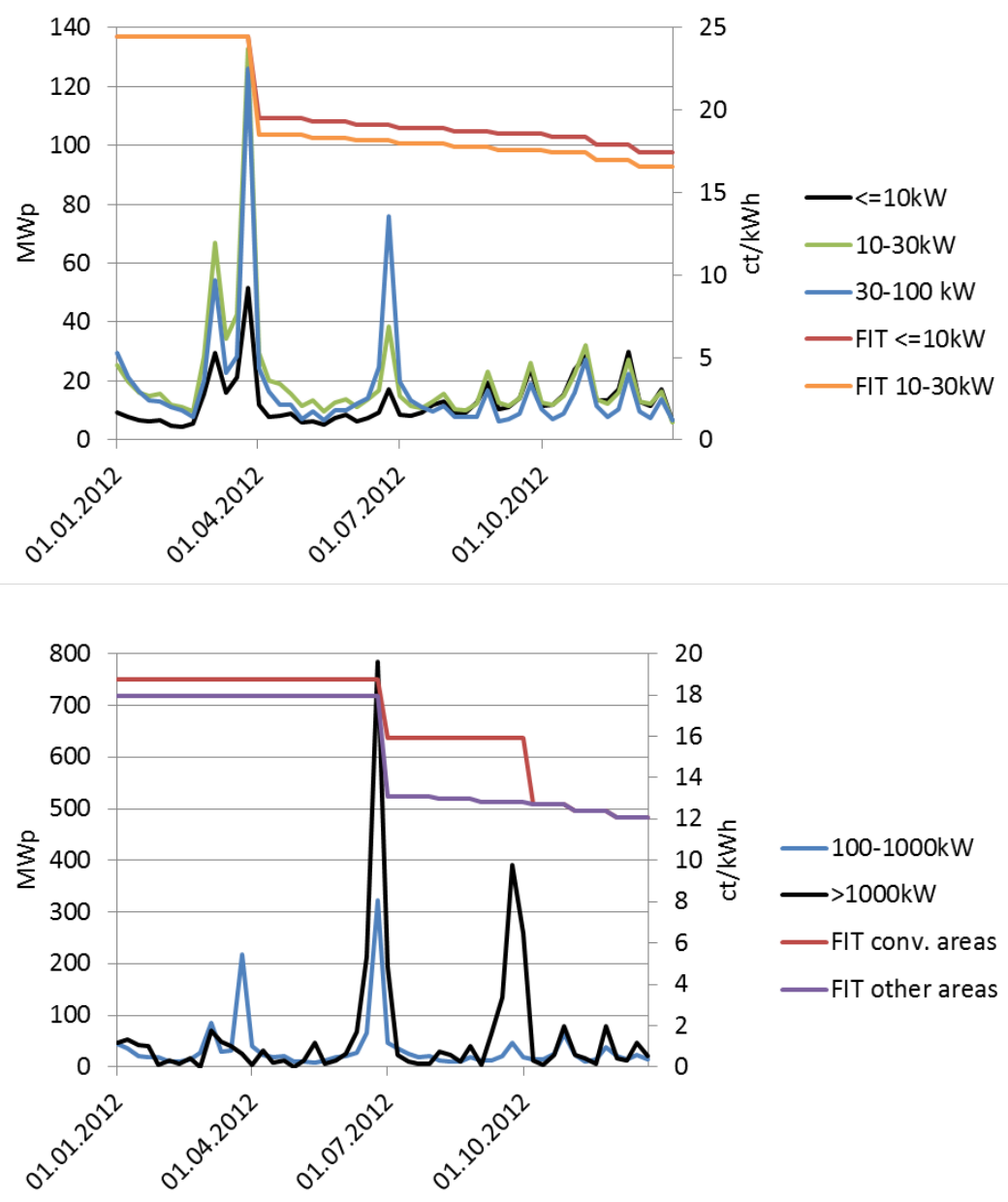
Investor behavior was clearly responsive to the various transitional provisions implemented by the government (see section 2.1). First, we observe strong demand peaks for small-scale systems in March 2012, prior to the respective one-off tariff reductions in April. These one-off tariff cuts were announced before the government released the new version on the feed-in tariff adjustment mechanism at the end of June. Small-scale installations slightly peaked again in June, prior to this release. Second, the strong demand peaks of large installations above $1 \mathrm{MW}$ at the end of June and September 2012 respectively indicate that this size category mainly contains ground-mounted installations.

This market development illustrates that the monthly feed-in tariff adjustment frequency is actually implemented since April 2012 for small installations, and since July 2012 for ground-mounted plants. Figure 2 shows weekly deployment for small rooftop and large ground-mounted systems since October 2012.

Figure 2: Weekly PV installations for small and large installations in Germany between October 2012 and July 2013

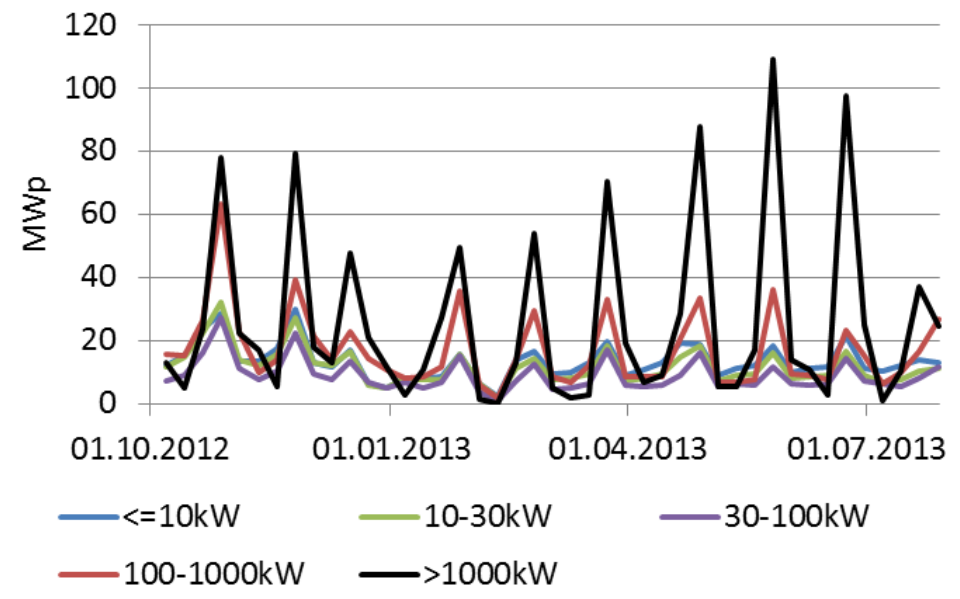

While demand peaks appear for all system size categories prior to the monthly feed-in tariff adjustments, these peaks are particularly strong for larger installations. This illustrates that largescale installations are more responsive to changing support schemes.

The same market behavior can be observed when analyzing the previous time period between January 2009 and September 2012. Table 2 shows deployment peak intensity defined as the deployment within the last two weeks prior to a feed-in tariff reduction compared to the deployment in the weeks before with constant feed-in tariffs.

Table 2: Deployment peak intensity

\begin{tabular}{|l|r|r|r|r|r|}
\hline & $<=10 \mathrm{~kW}$ & $10-30 \mathrm{~kW}$ & $30-100 \mathrm{~kW}$ & $100-1000 \mathrm{k}$ & $>1000 \mathrm{~kW}$ \\
\hline 2009 W51-52 & 2.4 & 3.5 & 6.5 & 11.9 & 9.1 \\
\hline 2010 W25-26 & 4.6 & 6.0 & 8.6 & 12.6 & 14.8 \\
\hline 2010 W38-39 & 3.0 & 2.8 & 2.8 & 2.5 & 1.6 \\
\hline 2010 W51-52 & 1.7 & 2.4 & 4.0 & 5.7 & 5.4 \\
\hline 2011 W51-52 & 3.3 & 4.8 & 7.8 & 13.2 & 14.8 \\
\hline 2012 W12-13 & 3.6 & 3.8 & 3.9 & 4.3 & \\
\hline 2012 W25-26 & & & & & 18.8 \\
\hline 2012 W39-40 & & & & & 7.2 \\
\hline
\end{tabular}


This illustrates the extent to which deployment is responsive to extraordinary changes in profitability through abrupt policy changes. We observe that deployment peak intensity usually increases (from small values marked in green to high values marked in red) with project scale. While small-scale deployment $(<=10 \mathrm{~kW}$ ) peaks by a factor of 3.1 on average, large-scale deployment peaks more than threefold stronger.

Figure 3 shows the relationship between deployment peak intensity and feed-in tariff reductions for small systems ( $<=10 \mathrm{~kW}$ ) and large-scale installations (>1 MW) between 2009 and September 2012.

Figure 3: Deployment peak intensity and feed-in tariff reductions for small and large-scale systems between January 2009 and September 2012

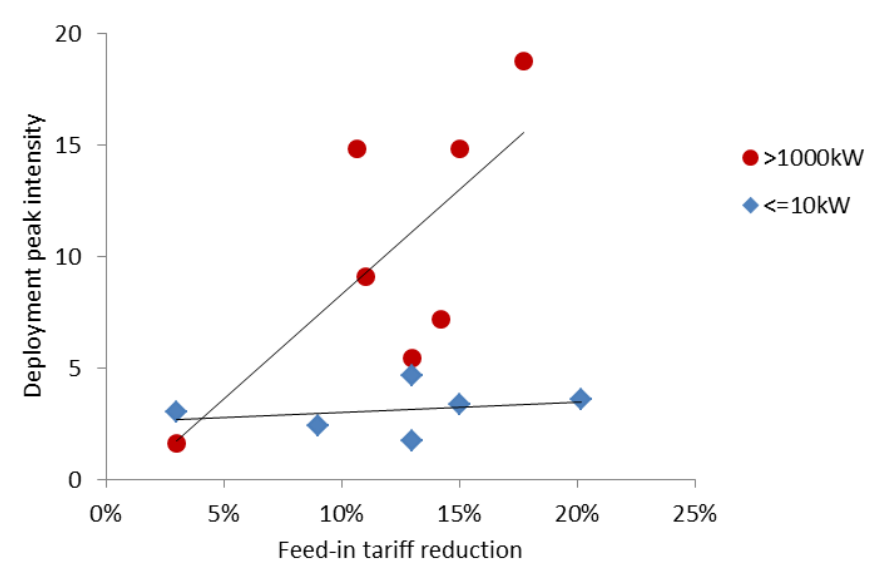

While deployment peak intensity is relatively constant across feed-in tariff adjustments for small systems, peak intensity increases with the magnitude of feed-in tariff reduction for large-scale installations. This shows a combination of two factors: Project development companies with largescale industrial plants have more flexibility to adjust project execution to meet certain commissioning dates, and they respond more strongly to price signals than private investors with residential rooftop systems.

\section{Remuneration, system prices, and project durations}

Feed-in tariff remuneration is paid for a time period $n$ of 20 years. PV plants reach around 900 full load hours $h$ per year in Germany. Yearly interest rates $i$ are based on data published by (Bundesbank, 2013) for each month between January 2009 and August 2013.

Small-scale residential PV systems account for the largest specific investment costs per kWp, as they need the highest relative effort for project development and installation. Large-scale groundmounted PV plants exhibit much lower system prices due to quantity discounts and standardization effects. The monthly system prices data between January 2009 and August 2013 for PV systems up to $100 \mathrm{kWp}$ (after tax) from Photovoltaik-guide (2013) is therefore adjusted for different system sizes with fixed shift factors. Based on system size specific price data from IEA (2011) and Reichmuth (2011), small-scale systems up to $10 \mathrm{kWp}$ are calculated to be $18 \%$ more expensive (than systems of $100 \mathrm{kWp}$ ), while installations larger than $1 \mathrm{MWp}$ are $25 \%$ cheaper than systems up to $100 \mathrm{kWp}$.

The PV GRID database (PVGrid, 2014) provides detailed information on process duration, waiting time, labor requirements, and legal-administrative cost shares for all PV project development stages in different European countries. According to the database, project durations are relatively short for 
small-scale ( $3 \mathrm{kWp}$ ) residential PV systems ( 7 weeks on average) and mid-scale ( $50 \mathrm{kWp}$ ) commercial projects (9 weeks) in Germany. However, large-scale (2.5 MWp) industrial ground-mounted projects have significantly higher project durations, with 40 weeks on average. Moreover, while project duration ranges for small PV systems (between 5 and 10 weeks) and commercial installations (between 5 and 15 weeks) are relatively similar, these durations range between 24 to 53 weeks for large plants.

For the purpose of this deployment model, project durations $d$ correspond to the respective average durations. Figure 4 shows weekly installations and profits (net present values calculated based on equations 2 and 3) for small and large projects for the time period 2009 until 2011.

Figure 4: Weekly installations and profits for small and large systems in Germany between 2009 and 2011

Projects $<=10 \mathrm{~kW}$

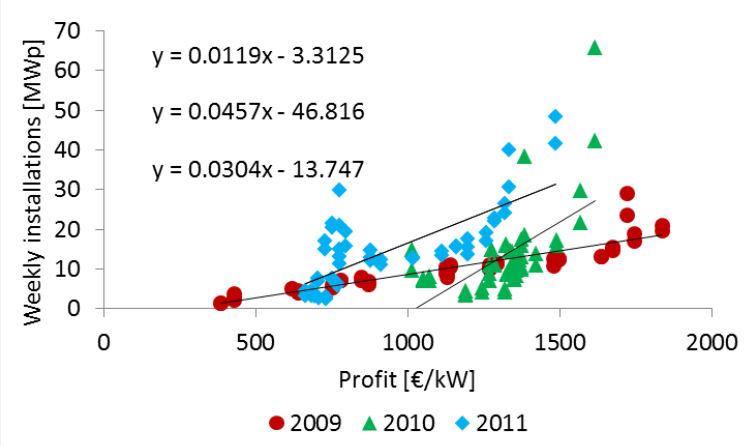

\section{Projects $>1 \mathrm{MW}$}

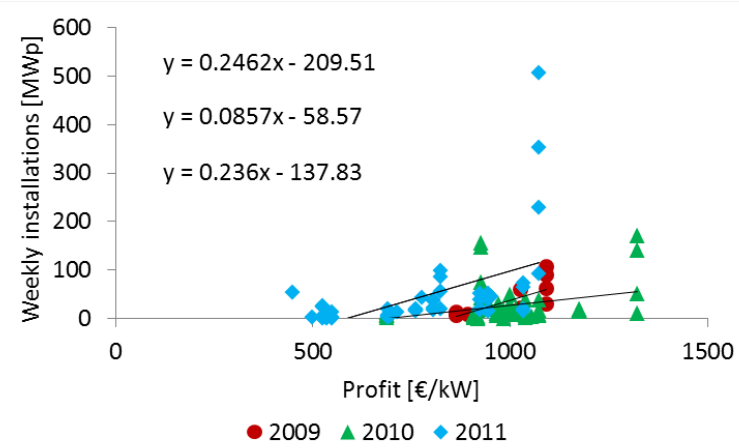

Deployment positively correlates with project profitability for both small residential and large industrial PV projects. Large installations are more responsive to changes in profitability, as indicated by the higher slopes of the respective linear trendlines. Moreover, as mentioned before, we observe stronger peaks of large installations. This can be due to their longer project durations and larger duration ranges, which enable project developers to accelerate large projects to a higher extent than small projects prior to feed-in tariff adjustments.

To adequately represent the new feed-in tariff mechanism with its high adjustment frequency, the deployment model is based on data since the implementation of the monthly feed-in tariff adjustments. Figure 5 shows weekly installations and profits (net present values calculated based on equations 2 and 3 ) for small rooftop systems (<= $10 \mathrm{~kW}$ ) and large-scale plants ( $>1 \mathrm{MW}$ ) from April and July 2012 respectively until July 2013. 
Figure 5: Weekly PV installations and profits in Germany since the implementation of monthly feed-in tariff adjustments (April and July 2012 respectively until July 2013)

Projects $<=10 \mathrm{~kW}$

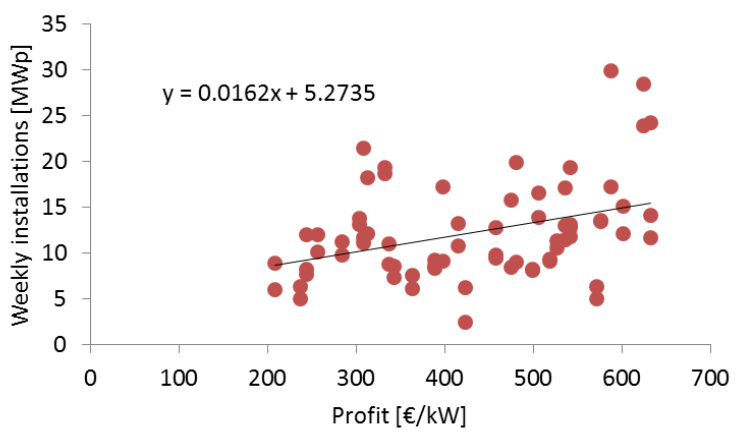

Projects $>1 \mathrm{MW}$

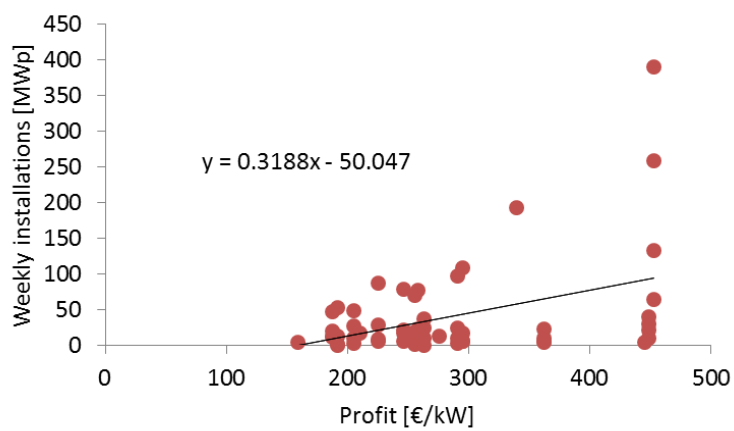

A similar market behavior can be observed after the implementation of monthly feed-in tariff adjustments. Deployment positively correlates with project profitability for both small and large projects, with the regression coefficients being significant ( $p$ value of 0.001 ). The figure illustrates that again large installations are more responsive to changes in profitability levels.

\subsection{Deployment model simulation and results}

This section uses the analytic deployment model (see section 3.1) to simulate weekly PV installations and responsive feed-in tariff levels for different project scales under the current feed-in tariff adjustment mechanism in Germany. The simulation period is three years from August 2013 until July 2016 for weekly deployment, and between November 2013 and July 2016 for responsive feed-in tariff levels.

The simulation takes into account small residential systems $(<=10 \mathrm{~kW})$ and large industrial plants $(>1$ $\mathrm{MW}$ ). The model could also be used to analyze deployment effectiveness of various mid-size project scales. The market share of the selected categories between 2009 and 2012 was 10 percent $(<=10$ $\mathrm{kW}$ ) and 29 percent (>1 MW) respectively. With regard to the overall annual deployment target corridor of between 2.5 and $3.5 \mathrm{GW}$, these shares would correspond to separate weekly installation target corridors of between 4.8 and $6.7 \mathrm{MW}$ for small systems (<= $10 \mathrm{~kW}$ ), as well as between 13.8 and 19.3 MW for large plants (>1 MW) respectively. As mentioned before, one policy objective is that PV deployment develops within a given target corridor.

To ensure that deployment of each size category starts within the respective target corridor at the beginning of the simulation period, starting prices are calibrated: Taking into account the respective project durations (see section 4.1), the price for small systems ( $<=10 \mathrm{~kW}$ ) is set at $2041 € / \mathrm{kW}$ in the week of 16 June 2013, while the price for large plants (>1 MW) is set at $1222 € / \mathrm{kW}$ in the week of 28 October 2012. To calculate new feed-in tariff degression rates in November 2013 and February 2014, the model assumes that deployment levels within the respective qualifying periods correspond to the $3 \mathrm{GW}$ yearly target corridor. From May 2014 onwards, degression rates are calculated depending on deployment in the respective previous 12 months, as defined by the law. 
Due to the dynamic evolution of historic PV system prices, their future development is difficult to predict. Therefore, three possible price scenarios are used to simulate the achievement of deployment targets for different project scales. If deployment evolves within its target corridor, the current feed-in tariff adjustment mechanism in Germany sets basic degression rates at one percent per month, which correspond to an annual degression of 11.4 percent. In the first scenario, PV system prices therefore continuously decrease by corresponding 12 percent on a yearly basis. In the second scenario, prices decrease by 22 percent per year, according to the yearly average price reduction between January 2009 and January 2013. As module prices recently increased due to trade disputes between the European Union and China, the third scenario uses a yearly system price reduction of only 9 percent per annum.

Figure 6 shows model results for weekly PV deployment of different project scales within the German feed-in tariff adjustment mechanism under the three system price scenarios.

Figure 6: Model-based simulated weekly PV installations and target corridors for small and large projects with responsive feed-in tariff adjustment under different price scenarios

Scenario 1 with 12 percent yearly price decrease

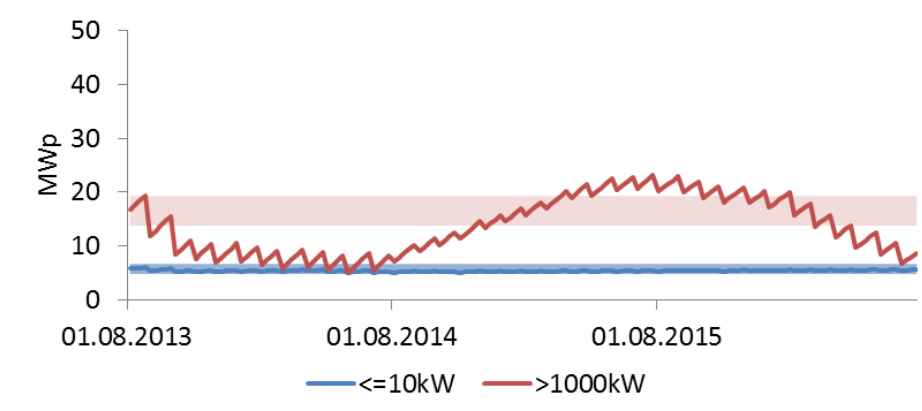

Scenario 2 with 22 percent yearly price decrease

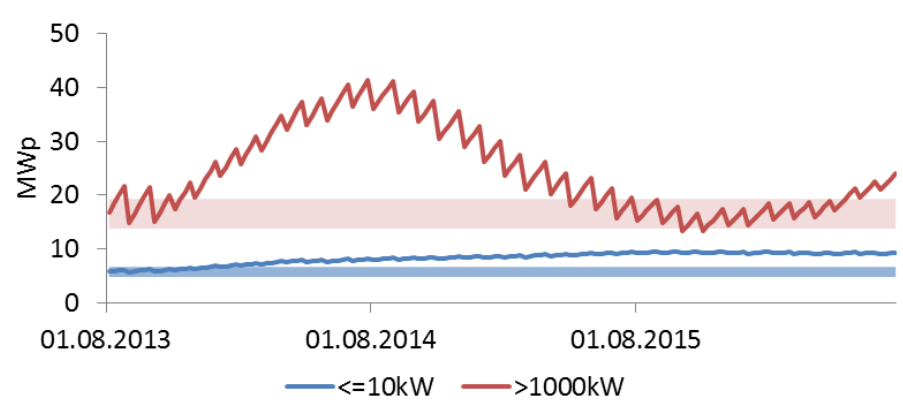

Scenario 3 with 9 percent yearly price decrease

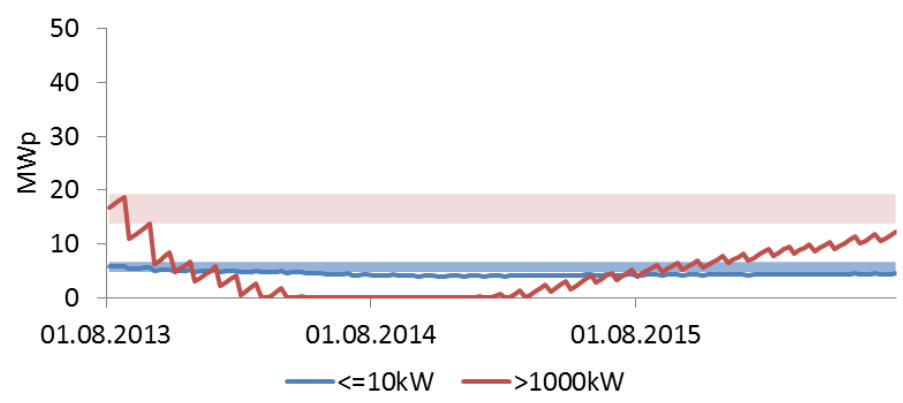


Weekly PV deployment of small systems develops within the respective target corridor in price scenario 1 , as system prices decrease according to basic feed-in tariff degression rates. Due to their stronger responsiveness to changes in profitability, simulated deployment of large installations develops more volatile. After large installations initially fall below the target corridor in scenario 1 , the responsive feed-in tariff mechanism leads them back on track in November 2014.

If module and installation prices develop very differently from the envisaged trajectory, installation volumes will strongly deviate from their target corridors. This is due to the design of the current responsive feed-in tariff scheme in Germany: There is no real-time adjustment of feed-in tariffs to system price levels, but tariffs are adjusted depending on installations in the respective previous 12 months. Furthermore, the Federal Network Agency only publishes actual deployment and corresponding degression levels with one month lag. Therefore, this mechanism leads to a time lag between changes in system prices and feed-in tariff adjustments.

If system prices decrease by larger rates, as shown in scenario 2, profitability margins increase, causing excess deployment. This leads to increasing feed-in tariff degression rates, but because of the time lag mentioned before installations further increase until July 2014 for large plants (41.5 MW maximum weekly deployment, corresponding to $252 \%$ target achievement relating to corridor center), and until December 2015 for small projects (9.5 MW maximum weekly deployment, corresponding to $167 \%$ target achievement relating to corridor center). Responsive monthly feed-in tariff degression rates therefore reach a maximum level of 2.2\% for large installations between November 2014 and July 2015, and of 1.8\% for small systems between November 2015 and July 2016 respectively. The advanced deployment model developed by Grau (2012) can be used to show that flexible feed-in tariff adjustment mechanisms with shorter qualifying periods ( 3 months instead of 12 months) are faster in correcting excess deployment for small-scale installations.

Scenario 3 shows a similar development: weak price reductions lead to smaller profitability margins, resulting in deployment below target corridors. The relatively low profit margins of large-scale projects even prevent any deployment between May 2014 and December 2014. However, the responsive feed-in tariff adjustment scheme is able to correct this trend from the beginning of 2015 onwards.

The major difference in deployment deviating from target corridors across project scales lies in the respective orders of magnitude. As large-scale PV projects are more responsive to changes in profitability levels (see section 4.1), the model simulations clearly illustrate that resulting target deviations are much stronger for large plants than for small systems.

Table 3 shows model results for PV deployment in Germany (yearly averages), target corridors, and target achievement (relating to center of target corridor) for small and large PV plants under different price scenarios.

Table 3: Yearly target corridors, simulated annual deployment, and target achievement

\begin{tabular}{|l|l|l|l|l|l|l|l|l|l|}
\hline \multirow{2}{*}{} & \multicolumn{3}{|l|}{ Target corridor [MWp] } & \multicolumn{3}{l|}{ Simulated deployment [MWp] } & \multicolumn{3}{l|}{ Target achievement [\%] } \\
\cline { 2 - 10 } & from & to & mid & Sc. 1 & Sc. 2 & Sc. 3 & Sc. 1 & Sc. 2 & Sc. 3 \\
\hline$<=10 \mathrm{~kW}$ & 247 & 346 & 296 & 277 & 429 & 230 & $93 \%$ & $145 \%$ & $78 \%$ \\
\hline$>1000 \mathrm{~kW}$ & 715 & 1001 & 858 & 716 & 1259 & 237 & $83 \%$ & $147 \%$ & $28 \%$ \\
\hline
\end{tabular}


For the responsive feed-in tariff mechanism in Germany, simulated deployment develops on average within the respective target corridors in scenario 1 . Table 3 illustrates that target deviations are stronger for large-scale plants than for small systems. If deviations below and above the target corridor were considered to be equally relevant in terms of deployment effectiveness, target deviations in the scenarios evaluated are $50 \mathrm{MWp}$ for small projects and $368 \mathrm{MWp}$ for large installations on average in absolute terms (relating to corridor boundaries). Target achievement in relative terms (relating to corridor centers) is similar for small and large projects in scenario 2 , but differs strongly in scenario 3.

The model results show that responsive feed-in tariff schemes with frequent tariff adjustments are able to reach deployment targets relatively effectively for small-scale PV systems. However, for large installations, the target corridor is more difficult to reach with flexible feed-in tariff adjustment mechanisms.

Tender schemes with set quantities for large-scale installations could improve overall achievement of deployment targets. However, there are large differences in actual implementation rates of approved projects in countries with tenders. In the UK, the Non-Fossil Fuel Obligation (NFFO) tendering scheme resulted in contracts for $3270 \mathrm{MW}$ of wind power declared net capacity (DNC) between 1990 and 1998, but only 29\% of these projects were realized by September 2003 (Butler and Neuhoff, 2008). In California, a typical assumption is that $40 \%$ of projects contracted through tenders will be commissioned (expert interview).

\section{$5 \quad$ Results on cost effectiveness factors}

This section describes the interview sample, and subsequently presents and analyzes interview results on specific factors impacting cost effectiveness, in particular cost of capital and transaction costs, of feed-in tariffs and tenders in selected countries.

\subsection{Interview sample}

The results in this study are based on interviews with 21 experts from 19 German and French PV project development companies. These companies include large vertically integrated firms who develop, construct and operate projects, as well as small specialized firms. Around 60 percent of these firms have more than 100 employees. The experts interviewed include several chief executive officers, as well as directors and project managers. The interviews were conducted between May and October 2013 , by phone and at a solar industry fair.

The project developers interviewed are engaged in PV projects around the world, and have most experience with project development under a tendering scheme in France (12 companies), followed by South Africa (10 companies). Other countries mentioned include India, Turkey, the US, Australia, Portugal, Cyprus, Indonesia, Bangladesh, Ghana, Botswana, Mexico, and Chile.

The following sections will therefore mainly focus on a comparison of the German feed-in tariff system with the tendering schemes in France, and partially South Africa, due to the large amount of interview results obtained for these countries. 


\subsection{Cost of capital}

Before developing a PV project, investors and lenders assess the risks involved in the remuneration mechanism and the country in focus. The higher the risks involved, the larger are required returns on equity and debt interest rates. Project financing costs increase with higher equity shares, cost of equity and loan interest rate. This section focuses on the effects of feed-in tariffs and tenders on the weighted average cost of capital, by comparing equity shares as well as cost of equity and debt across policy schemes.

The results from the semi-structured expert interviews are grouped into 5 categories within this section: a residential rooftop system ( $5 \mathrm{kWp}$ ), two commercial rooftop systems (50 and $200 \mathrm{kWp}$ ), and two ground-mounted systems ( 1 and $5 \mathrm{MWp}$ ). The majority of project developers interviewed focus their business on large installations.

Figure 7 shows equity shares in project financing reported by project developers for different project scales (in kWp) in Germany, with minimum, average, and maximum values.

\section{Figure 7: Equity shares across project scales in Germany}

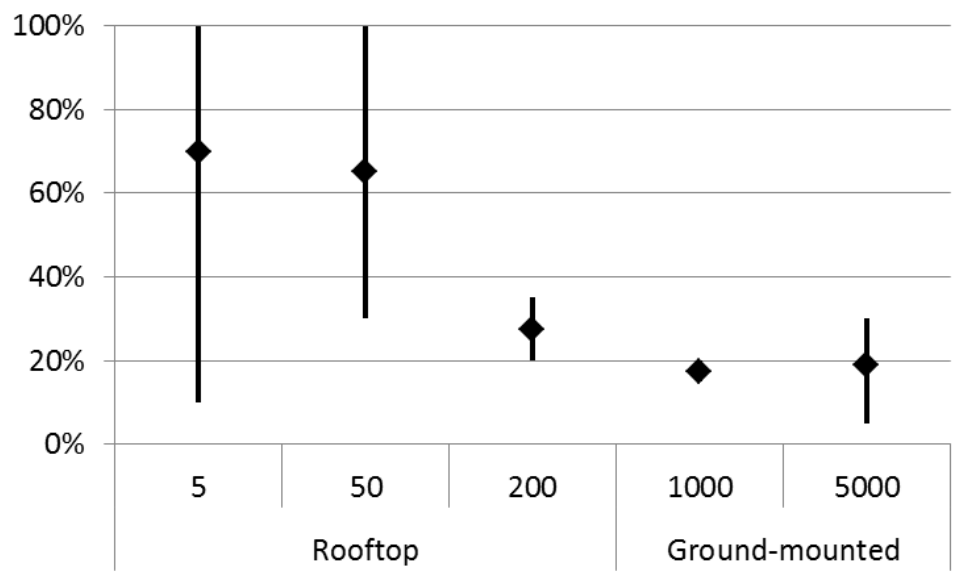

Interview results show that equity shares in project financing tend to decrease with increasing system size. Private investors usually finance their small residential PV systems with high equity shares, and in recent years often by equity only. Companies investing in large-scale projects use higher shares of debt financing. Due to the leverage effect, use of low interest debt leads to lower overall support costs. While a $20 \%$ equity share for investing in ground-mounted plants is common, the share is slightly higher for large rooftop systems.

To finance projects in countries with tendering schemes, project developers use similar shares of equity, with values on average being $30 \%$ for large rooftop systems ( $200 \mathrm{kWp}$ ) and $20 \%$ for groundmounted installations ( 1 and $5 \mathrm{MWp}$ ) in France, and 23\% for ground-mounted plants in South Africa. Therefore, the differences between feed-in tariff remuneration and tendering schemes seem to have an insignificant impact on equity shares in project financing.

Figure 8 shows cost of equity and cost of debt for investing in different project scales in Germany, France and South Africa, with minimum, average, and maximum values. 
Figure 8: Cost of equity and cost of debt across project scales in Germany, France and South Africa

\section{Cost of equity}

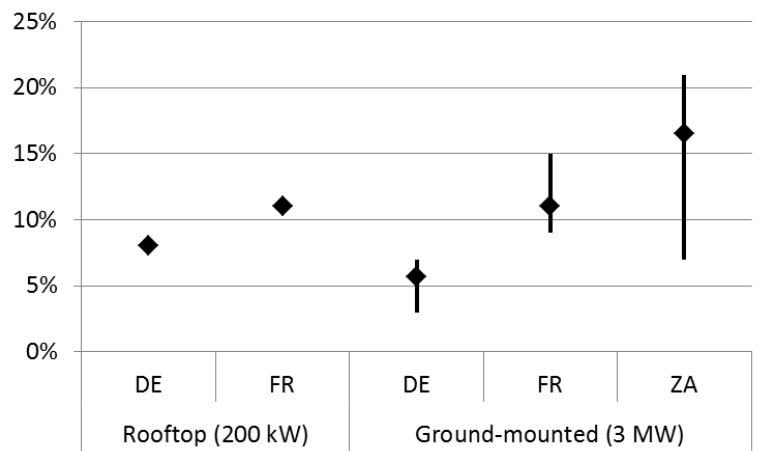

Cost of debt

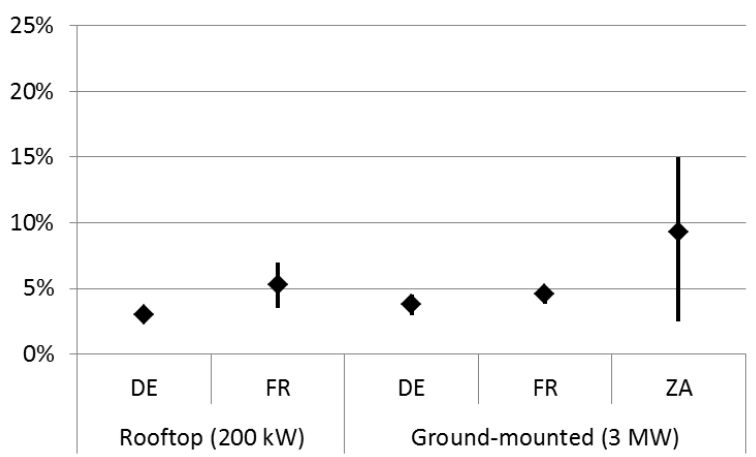

The cost of equity (required rate of return on equity) is generally higher than the cost of debt (debt interest rate). Equity providers get compensated with larger returns, as they face higher risks in project financing than lenders.

Project developers reported that the cost of equity is higher under tendering schemes than under the German feed-in tariff scheme across project scales. While the average cost of equity in France is three to five percent higher than in Germany, it is even 11 percent higher in South Africa.

For debt financing in Germany, project developers often use the 'Erneuerbare Energien' program from the KfW (Kreditanstalt für Wiederaufbau) bank. Similar to the cost of equity, the cost of debt is always lowest in the German feed-in tariff system compared to France and South Africa with their tendering schemes. However, country risks might have an additional impact on both cost of equity and cost of debt.

Figure 9 shows the weighted average cost of capital for different project scales under feed-in tariffs and tenders. WACC levels were calculated across project scales for the German feed-in tariff and the French tendering scheme (based on equation 4), and reduced by the yields of the respective ten year government bonds, to correct for country risks.

Figure 9: Weighted average cost of capital above yields of ten year government bonds, across project scales in the German feed-in tariff and the French tendering scheme

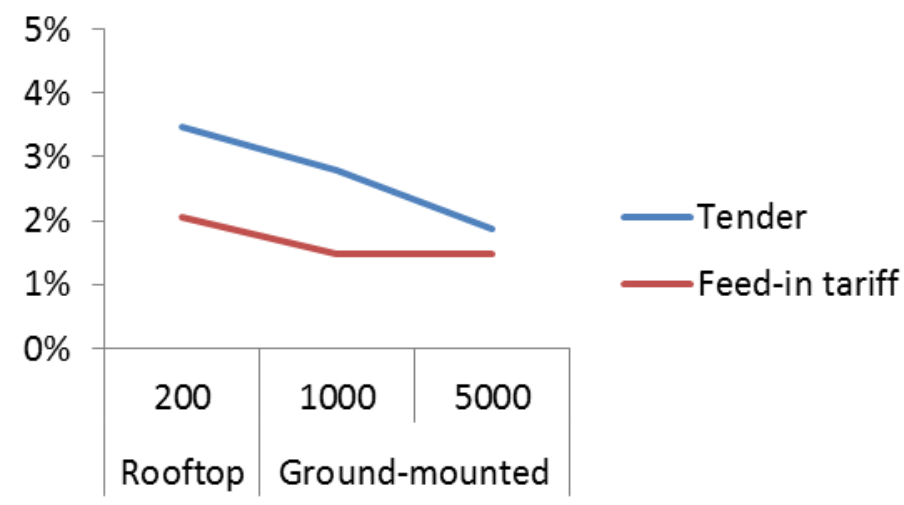

The weighted average cost of capital in the German feed-in tariff system (between $3.2 \%$ and $3.7 \%$ ) is lower than in France (between 4.1\% and 5.8\%) and South Africa (around 9\%) with their tendering 
schemes. This is due to the lower cost of capital and debt. The yields of ten year government bonds amount to $1.69 \%$ for Germany, and to $2.28 \%$ for France (Bloomberg, 2014). The corporate tax rate is 29.55\% in Germany, and 33.33\% in France (KPMG, 2014). The relationship between the national WACC levels also holds without considering the corporate tax rate.

The German feed-in tariff reduces risks in comparison to the French tendering scheme, which leads to lower WACC levels. However, we observe that WACC levels in Germany and France converge for large ground-mounted PV plants.

\subsection{Transaction costs}

The results from the semi-structured interviews revealed the following transaction cost categories being most important for a comparison of tenders and feed-in tariffs:

- Project development times

- Project development costs

- Project implementation success rates

- Innovation barriers

- Costs for bureaucracy

- Costs for the supply chain (in the case of tenders with low frequency)

With regard to overall cost effectiveness, some project developers argued that project development rents are larger in tender systems due to long tender periods and lack of competition, as in general only large companies have the capabilities to participate in tenders. However, private investors are usually pleased with lower returns on their investments in comparison to large companies. But rents may also be higher in feed-in tariff schemes because of higher profit margins due to inadequate feedin tariff adjustments. In this regard, large-scale installations imply a particularly high risk of overcompensation (excessive rents). Therefore, to carefully equalize profitability across project scales, tenders seem to be more promising for large plants.

As mentioned in section 3.2.2, the focus of this analysis is on the project development phase. Therefore, the following section focuses on the first three transaction cost categories, as (i) interview results allowed to quantify the respective costs, and (ii) they are considered to be of particular relevance for various experts. The other categories are discussed thereafter.

\section{Project development stages and times}

PV project development covers the following main development stages: site selection, financing, administrative process, and grid connection permit. Figure 10 illustrates a typical project development timeline with individual project steps and sub-categories. 
Figure 10: Project development stages

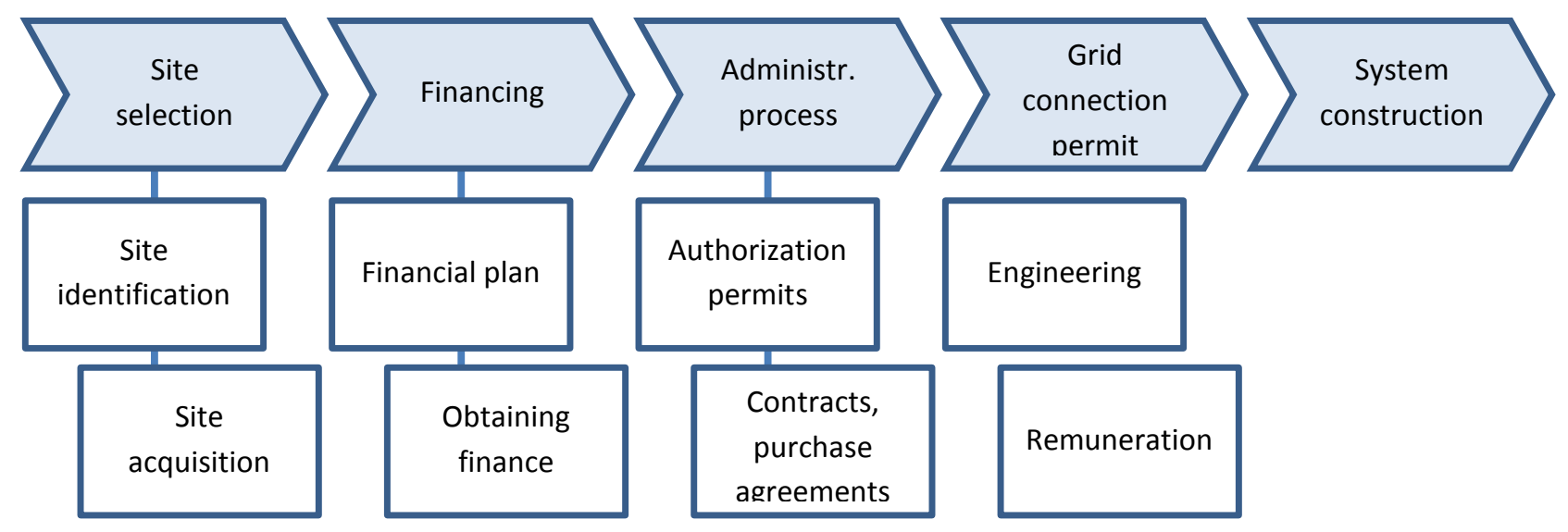

Figure 11 shows average project development times for PV projects in Germany across size categories. Project development under the German feed-in tariff system takes between 3 to 11 weeks for rooftop PV systems on average, and more than 30 weeks for ground-mounted plants, according to interview results and data from (PVGrid, 2014). The grid connection permit represents the longest process stage for rooftop systems, while the administrative process takes longest for ground-mounted plants.

\section{Figure 11: Project development times in Germany}

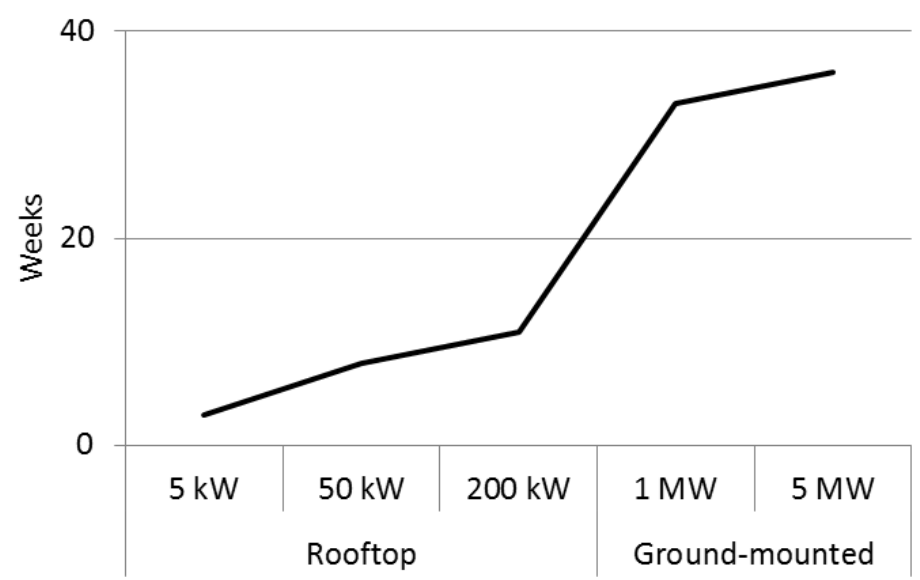

Ground-mounted installations imply significantly longer project development times as they need a construction permit in Germany, in comparison to rooftop systems (which need a statics certificate). Project development for ground-mounted systems takes around 9 months, including the arrangement for a land development plan (which can take up to more than a year) and a construction permit (which takes around 12 to 16 weeks). Project developers reported that modules are usually purchased 6 to 8 weeks before system construction. The construction phase takes around 5 weeks. Thus, project developers need planning security for around one year for ground-mounted plants.

Tenders lead to longer project development times in comparison to feed-in tariff schemes, because of the tender time which is related to the additional bureaucracy. Moreover, after winning the tender, there might be less incentives to quickly install the plant than under a flexible feed-in tariff adjustment scheme. 
Tenders in France take between 3 months and 4 years, according to expert interviews. The time between filing an application and obtaining a construction permit was reported to be between 8 to 18 months. Before participating in a tender, a project developer gets in contact with module producers and can sign an option contract to reduce risk. After winning a tender sometimes everything gets renegotiated with module manufacturers. As obtaining financing takes around 3 months, modules are usually purchased after about one year. The environmental survey takes around 12 months. After winning a tender, the company has a time period of 18 months to build the plant. For each quarter the company might be delayed with building the plant, the remuneration period (usually 20 years) gets reduced by one month.

Tenders in South Africa were reported to take between 5 months and 2 years, with acceptance of bids occurring three times per year.

\section{Project development costs}

Project development costs per installed capacity decrease with increasing system size, as shown by Figure 12 for Germany. However, small ground-mounted installations are more expensive to develop than large commercial rooftop systems. This is because project development for ground-mounted plants needs to secure the land and a construction permit. Companies usually finance the project development phase only with equity, and the phases thereafter then also with debt.

\section{Figure 12: Project development costs in Germany}

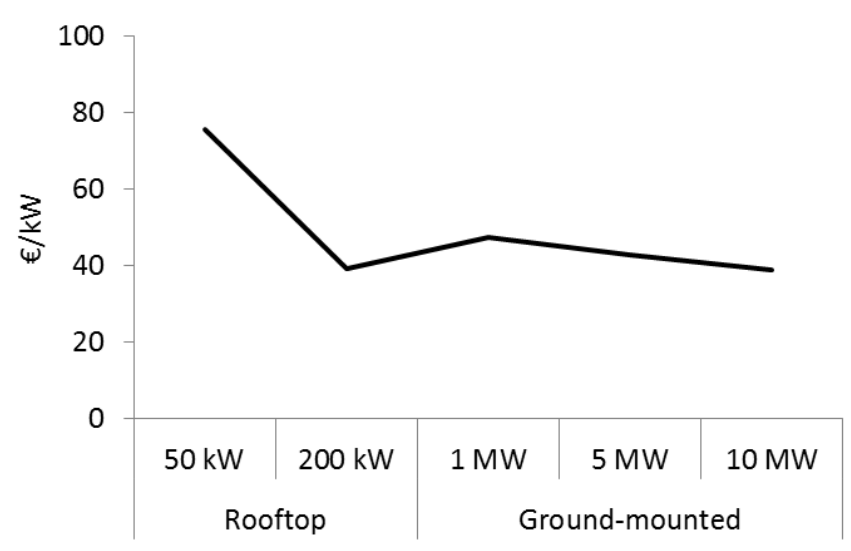

Tenders imply larger project development costs (in comparison to feed-in tariffs) like labor costs for additional documents, costs for collaterals, or marketing costs. In France, additional documents required in tenders include documents for collaterals, on research projects, and $\mathrm{CO}_{2}$ balance sheets. The tenders in South Africa require an environmental impact assessment, audit reports, guarantees, and a grid compatibility assessment.

Collaterals are usually requested as securities to avoid non-performance. Factors which led to nondelivery after winning a tender were reported to be overestimation of capacities concerning finance and human capital. Project developers reported that collaterals are among the most important transaction costs of tenders. 
In the French PV tender 2011/2012 for installations larger than $250 \mathrm{~kW}$ an implementation collateral of $50000 € / \mathrm{MWp}$ was required to guarantee implementation of the project (CRE, 2011). ${ }^{1}$ Project developers needed to deposit the money for the implementation collateral (corresponding in size roughly to development costs) at the bid with a confirmed bank guarantee for 12 to 24 months, until grid connection and commercial operation. This means that capital requirements for project development double with the collateral.

\section{Project implementation success rates (and related risks)}

In Germany, project development success rates were reported to be around 80 to $90 \%$ for small private systems, around $50 \%$ for commercial rooftop systems (with statics and renovation being most critical), and around $20 \%$ for ground-mounted systems. Investments in project development of ground-mounted systems are of highest risk because of requirements concerning planning law and ground investigation (land-use plan), as there is no certainty if the project will finally receive construction approval. The main risks are in the administrative process stage. Monthly feed-in tariff adjustments lead to additional planning uncertainty.

Within the current German feed-in tariff adjustment design, companies investing in large-scale projects face uncertain final feed-in tariff rates during the long process of project development. Additionally, there is uncertainty about module prices, and therefore about investment costs. Both uncertainties are correlated and thus expected to partially compensate. Hence, project developers reported that the risks inherent to a tender system outweigh the respective risks under a responsive feed-in tariff scheme.

As tenders imply lower project development success rates, investors need to develop more projects to at least get the chance to implement some of them. In the French PV tender 2011/2012 for ground-mounted installations projects with a cumulative capacity of $1041 \mathrm{MWp}$ applied for a quota of $162.5 \mathrm{MWp}$. Projects with a cumulative capacity of $183.8 \mathrm{MWp}$ were finally accepted. This is equivalent to a $18 \%$ success rate. In South Africa, a $10 \%$ success rate between application and winning a tender was reported. This illustrates that in tendering systems companies need to develop several projects to at least get the chance to implement some of them. Moreover, experience with tenders shows that only certain shares of approved projects have actually been realized (see section 4.2 for examples).

In the project development phase, the site selection stage has higher risks under a tender, as it is more difficult to get suitable lands due to the lower success rate. The financing stage was reported with a $30-40 \%$ higher risk under a tender because of bankability. The administrative process in tenders also usually poses higher risks than in feed-in tariff systems. In the French tenders for installations larger than $250 \mathrm{~kW}$, the price gets only 12 points out of overall 30 points, the rest are environmental and R\&D criteria (see section 2.2). Project developers reported that there is high uncertainty about why some projects were successful in the French tenders and other were not, as one does not receive a statement about the reasons for the respective decision.

\footnotetext{
${ }^{1}$ In this tender also a deconstruction collateral of $30000 € / \mathrm{MWp}$ was required to ensure dismantling of the plant. The deconstruction collateral needs to be deposited for the entire project duration until dismantling of the plant, i.e. for decades. It was reported that banks have difficulties to give money for this collateral type.
} 
Tenders imply higher uncertainties for project developers than feed-in tariffs. However, as soon as a company wins a tender, risks are lower under the tender (if the contract awarded through the tender includes interconnection and permitting (siting) guarantee) as remuneration rates are secure, so that companies can arrange for bank financing faster. Tenders then can ease financing, if they are well structured, in comparison to flexible feed-in tariff schemes. For banks it is important that the political support scheme secures constant remunerations.

\section{Innovation barriers}

According to project developers' experience, tender systems lead to less innovation compared to feed-in tariff schemes. If tenders impose specific technological requirements, companies are restricted in their ability to optimize projects. For instance, one French tender tries to foster innovation by requiring the implementation of tracker systems. To participate, companies must sign a contract for research and development. However, project developers reported that innovation driven by industry itself would be more effective. Tenders impose higher innovation barriers, as policymakers do not have perfect information about technology development. Moreover, long tender periods lead to a delay in technology development. This reduces the speed of the overall transition to a power system based on renewable energy sources.

\section{Costs for the supply chain}

Tenders often imply larger challenges for the industrial supply chain. A low frequency or irregular timing of tenders leads to stop and go cycles for industry. In France, tenders were delayed and application criteria were changed in the process, leading to decreasing confidence of project developers and additional challenges for industry. In South Africa, one tender round was cancelled by the government without specifying the reasons.

\section{Conclusion}

While feed-in tariffs are the most common policy instrument to support renewable electricity globally, more European countries apply them for small systems than for large installations, with more tenders being implemented for large-scale plants. Feed-in tariff levels are determined administratively by public authorities, while tendering schemes let investors compete to determine the required remuneration levels. As feed-in tariffs led to an overshoot of planned solar photovoltaics deployment in Germany between 2010 and 2012, automatic tariff adjustment mechanisms have been implemented. However, so far it remains unclear whether these mechanisms work effectively and efficiently for large PV systems.

This paper analyzes the trade-offs for using feed-in tariffs or tenders to support different scales of PV projects. The focus of the analysis is on both deployment effectiveness and specific factors impacting cost effectiveness, in particular financing and transaction costs. To measure deployment effectiveness in terms of achievement of installation targets, the paper develops an analytic model based on quantitative regression analysis to simulate deployment and tariff levels for different project scales in responsive feed-in tariff adjustment mechanisms under various future price scenarios. Semi-structured expert interviews with international project developers result in additional insights about specific factors impacting cost effectiveness under feed-in tariffs and 
tenders. As most interview partners reported on their experiences with tenders in France, this study compares cost of capital and transaction costs for the German and French remuneration schemes in detail.

Model results show that responsive feed-in tariff schemes with frequent tariff adjustments are able to reach deployment targets more effectively for small PV systems, while large installations impose additional challenges due to their significantly longer project durations and stronger responsiveness to changes in profitability levels and policy changes. Tenders with set quantities and appropriate incentives to realize successful applications may help to improve target achievement for large-scale plants. However, project implementation success rates largely differ across countries with tenders.

Project developers reported that the risks inherent to tenders outweigh the respective risks under feed-in tariff systems, especially for small projects. From an investor perspective, the current PV feed-in tariff mechanism in Germany with responsive monthly tariff adjustments across project scales imposes higher risks on large installations with longer project durations, as these systems face higher uncertainties about remuneration levels at project completion time. In case of winning a tender, the long-term contract can reduce this type of risk inherent in flexible feed-in tariff adjustment schemes.

Costs of equity and cost of debt are generally lower under feed-in tariffs than tendering mechanisms, while equity shares are relatively similar. Thus, the weighted average cost of capital is significantly lower under feed-in tariff schemes. However, WACC levels calculated based on interview results for feed-in tariffs and tenders converge for large ground-mounted plants, indicating that tendering schemes may be a cost effective alternative for installations above $5 \mathrm{MW}$ in Germany in terms of financing cost.

With regard to transaction costs, tenders lead to longer project development times, higher project development cost, and lower success rates, in comparison to feed-in tariffs. Moreover, tenders often led to higher market concentration, as usually only larger companies with sufficient financial capabilities and reference projects can participate and cope with the complexity of auction mechanisms. In general, the higher transaction costs of tenders seem to be better suited for large plants. When designing tenders, administrative barriers should be kept low, meaning that the amount of required documents to participate should be limited.

There are some limitations of this work which provide areas for future research. First, interview results on cost of capital and transaction costs are based on a sample size of 21 German and French project developers, with the majority being larger companies focusing on commercial and industrial PV systems. It would be interesting to further analyze additional factors impacting cost effectiveness, and to further assess risk evaluations of smaller companies and private investors, as well as project developers across other countries with feed-in tariffs and tenders. Second, while the German Renewable Energy Sources Act (EEG) was introduced in 2000, the French tenders for installations larger than $100 \mathrm{~kW}$ were only launched in 2011, meaning that experience with implementation rates and regulatory risks is higher for the remuneration scheme in Germany than for France. Third, the design of tenders largely differs across countries with regard to auction design, evaluation criteria, application processes, frequency, and regional distribution.

Policymakers usually focus on both deployment and cost effectiveness when designing renewables remuneration policies. An overall assessment of the effectiveness of PV remuneration across project scales for feed-in tariffs and tenders depends on the definitions and weightings of both effectiveness 
dimensions, as well as the framing and calibration of the corresponding indicators and criteria taken into account. In comparison to feed-in tariffs, tenders may improve deployment effectiveness and control on costs to ratepayers under specific circumstances for large projects. 


\section{Appendix}

\section{Interview questions}

\section{PV project developers}

Introduction: Feed-in tariffs have proven to be effective in deploying renewable energy sources. With regard to solar photovoltaics (PV), responsive feed-in tariff adjustment schemes are compatible with quantity targets for small-scale systems with short project durations. However, auction mechanisms may be more suitable for large installations to improve control on costs to ratepayers. The purpose of this research is to find an optimal threshold level between feed-in tariffs and tendering (or quota) schemes.

Disclaimer: Information acquired in this survey will only serve academic research. Your answers will be used confidentially and anonymously. In return for your participation in this interview, we will send you the results of the survey.

\section{$1 \quad$ General questions}

- What is your professional position within your company?

- In which major markets is your company active in PV project development? [Germany, Italy, France, UK, USA, China, India, other]

- In which countries do you have most experience with project development under a tendering and a quota scheme respectively?

- In which project stages is your company active? [Development, Construction, Operation]

- What is the size of your firm? [1-9, 10-100, >100 employees]

- What is the average size of your realized projects? [<100 kW, 100-1000 kW, >1 MW]

\section{$2 \quad$ Project development stages}

The following process durations (weeks) were identified for different project development stages and system sizes in Germany. ${ }^{2}$ Based on your international experience or discussions:

- Do you agree with these values for the case of the German feed-in tariff (FIT)?

- How would these values change in the case of a tender or quota system? If you consider a certain example, please specify the respective country.

- How do you explain the main differences?

\begin{tabular}{|l|c|l|l|l|l|l|}
\hline & \multicolumn{2}{|l|}{$\begin{array}{l}\text { Medium-scale rooftop (50 } \\
\text { kWp) }\end{array}$} & \multicolumn{3}{l|}{ Large-scale ground-mounted (2.5 MWp) } \\
\hline & FIT & Tender & Quota & FIT & Tender & Quota \\
\hline Site selection & 0 & & & 19 & & \\
\hline Financing & 0 & & & 16 & & \\
\hline Administrative process & 1 & & & 36 & & \\
\hline Grid connection permit & 8 & & & 19 & & \\
\hline System construction & 1 & & & 4 & & \\
\hline
\end{tabular}

\footnotetext{
${ }^{2}$ PV GRID - project funded by European Commission's Intelligent Energy Europe programme.
} 
The following project timeline shows development stages with individual sub-categories.

- Do you agree with this project development structure in the case of the German feed-in tariff system?

- How would these categories change in the case of a tender scheme (please specify country)?

- For how long are collaterals usually deposited for a medium- or large-scale project?

- How would the project structure change in the case of a quota scheme?

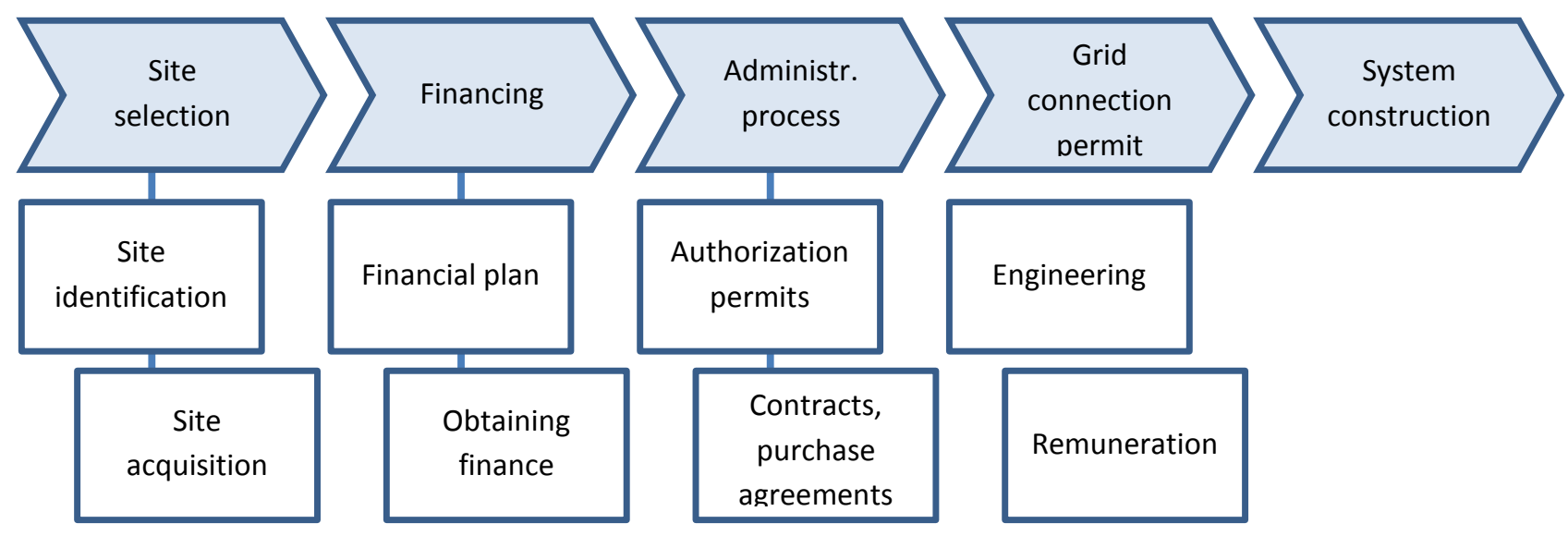

\section{$3 \quad$ Project risks}

There are numerous risk categories associated with the development of a PV project. These risks translate, depending on the type of the remuneration scheme, into different probabilities of project abandonment at each development stage. This section again compares the case of the German feedin tariff to your previous example of a tender and/or quota scheme.

- What do you consider, according to the following table, to be the main risks and the corresponding probabilities of abandoning a project at each of these stages?

- What is a typical success rate of winning tenders (what share of bids submitted was successful)?

\begin{tabular}{|l|l|l|l|l|l|l|}
\hline \multicolumn{2}{|l|}{ Feed-in tariff } & \multicolumn{2}{l|}{ Tender } & \multicolumn{2}{l|}{ Quota } \\
\hline & Risks & $\begin{array}{l}\text { \% aban- } \\
\text { doned }\end{array}$ & Risks & $\begin{array}{l}\text { \% aban- } \\
\text { doned }\end{array}$ & Risks & $\begin{array}{l}\text { \% aban- } \\
\text { doned }\end{array}$ \\
\hline Site selection & & & & & & \\
\hline Financing & & & & & & \\
\hline $\begin{array}{l}\text { Administrative } \\
\text { process }\end{array}$ & & & & & & \\
\hline $\begin{array}{l}\text { Grid connection } \\
\text { permit }\end{array}$ & & & & & & \\
\hline
\end{tabular}




\section{$4 \quad$ Project financing and cost of capital}

If you have experience with project development under different remuneration mechanisms, please select two of your recent projects with similar size category. If your focus is on one country, please select one recent project. The following questions focus on these specific projects.

- Which year and country where the respective projects commissioned in, and what is the size category?

- The following table focuses on project development (before system construction). What are the corresponding financial indicators for your projects?

- How did cost shares and debt-equity ratios differ across project development stages (site selection, administrative process, etc.)?

\begin{tabular}{|l|l|l|}
\hline & Feed-in tariff & Tender / quota \\
\hline Budget share spent on development & & \\
\hline Debt-equity ratio & & \\
\hline Cost of equity (return on equity) & & \\
\hline Cost of debt (loan interest rate) & & \\
\hline
\end{tabular}

- If you have experience with tenders, how does the need to deposit a collateral impact your project costs?

- What are other important transaction costs specific to tenders or feed-in tariffs?

Thanks a lot for your comments.

For questions please contact:

Thilo Grau

German Institute for Economic Research (DIW Berlin)

Mohrenstr. 58 | 10117 Berlin | Germany

Phone: +493089789473

Email: tgrau@diw.de

www.diw.de 


\section{References}

BATLLE, C., PÉREZ-ARRIAGA, I. J. \& ZAMBRANO-BARRAGÁN, P. 2012. Regulatory design for RES-E support mechanisms: Learning curves, market structure, and burden-sharing. Energy Policy, 41, 212-220.

BLOOMBERG. 2014. Government Bond Yields [Online]. Available: http://www.bloomberg.com/markets/rates-bonds/ [Accessed 12 February 2014.

BMU 2013. Zeitreihen zur Entwicklung der erneuerbaren Energien in Deutschland. In: BUNDESMINISTERIUM FÜR UMWELT, N. U. R. (ed.).

BMWI 2014. Eckpunkte für die Reform des EEG. Bundesministerium für Wirtschaft und Energie.

BNETZA. 2013. Bundesnetzagentur. Available: http://www.bundesnetzagentur.de/cln 1911/DE/Sachgebiete/ElektrizitaetundGas/Unterneh men Institutionen/ErneuerbareEnergien/Photovoltaik/photovoltaik-node.html

BRD 2010. Nationaler Aktionsplan für erneuerbare Energie gemäß der Richtlinie 2009/28/EG zur Förderung der Nutzung von Energie aus erneuerbaren Quellen. Bundesrepublik Deutschland.

BSW-SOLAR 2013. Statistische Zahlen der deutschen Solarstrombranche (Photovoltaik). Bundesverband Solarwirtschaft e.V. (BSW-Solar).

BUNDESBANK, D. 2013. Available: http://www.bundesbank.de/Navigation/DE/Statistiken/Zeitreihen Datenbanken/Makrooeko nomische Zeitreihen/its details value node.html?tsId=BBK01.SUD119.

BUTLER, L. \& NEUHOFF, K. 2008. Comparison of feed-in tariff, quota and auction mechanisms to support wind power development. Renewable Energy, 33, 1854-1867.

CGDD 2013a. Chiffres clés des énergies renouvelables. Edition 2013.: Commissariat général au développement durable.

CGDD 2013b. Tableau de bord éolien-photovoltaïque. Deuxième trimestre 2013.: Commissariat général au développement durable.

CHARPIN, J.-M. \& TRINK, C. 2011. Rapport de la concertation avec les acteurs concernés par le développement de la filière photovoltaïque. Paris.

COUTURE, T. \& GAGNON, Y. 2010. An analysis of feed-in tariff remuneration models: Implications for renewable energy investment. Energy Policy, 38, 955-965.

CRE 2011. Cahier des charges de l'appel d'offres portant sur la réalisation et l'exploitation d'installations de production d'électricité à partir de l'énergie solaire d'une puissance supérieure à $250 \mathrm{kWc}$. Commission de régulation de l'énergie.

CRE 2013a. Cahier des charges de l'appel d'offres portant sur la réalisation et l'exploitation d'installations de production d'électricité à partir de l'énergie solaire d'une puissance supérieure à $250 \mathrm{kWc}$. Commission de régulation de l'énergie.

CRE 2013b. Cahier des charges de l'appel d'offres portant sur la réalisation et l'exploitation d'installations photovoltaïques sur bâtiment de puissance crête comprise entre 100 et 250 $\mathrm{kW}$. Commission de régulation de l'énergie.

CUNHA, G., BARROSO, L. A., PORRUA, F. \& BEZERRA, B. 2012. Fostering Wind Power through Auctions: the Brazilian Experience. IAEE Energy Forum.

DEL RÍO, P. \& CERDÁ, E. 2014. The policy implications of the different interpretations of the costeffectiveness of renewable electricity support. Energy Policy, 64, 364-372.

EEG 2012. Gesetz für den Vorrang Erneuerbarer Energien (Erneuerbare-Energien-Gesetz - EEG). Konsolidierte (unverbindliche) Fassung des Gesetzestextes mit den Änderungen durch das „Gesetz zur Änderung des Rechtsrahmens für Strom aus solarer Strahlungsenergie und weiteren Änderungen im Recht der erneuerbaren Energien“ (sog. PV-Novelle) ed.

GRAU, T. 2012. Responsive Adjustment of Feed-in Tariffs to Dynamic PV Technology Development. DIW Berlin Discussion Paper 1189. 
HAAS, R., RESCH, G., PANZER, C., BUSCH, S., RAGWITZ, M. \& HELD, A. 2011. Efficiency and effectiveness of promotion systems for electricity generation from renewable energy sources - Lessons from EU countries. Energy, 36, 2186-2193.

IEA 2011. IEA PVPS National Survey Report of PV Power Applications in Germany 2010.

JAGER DE, D. \& RATHMANN, M. 2008. Policy instrument design to reduce financing costs in renewable energy technology projects. Ecofys.

KITZING, L., MITCHELL, C. \& MORTHORST, P. E. 2012. Renewable energy policies in Europe: Converging or diverging? Energy Policy, 51, 192-201.

KLEIN, A., MERKEL, E., PFLUGER, B., HELD, A., RAGWITZ, M., RESCH, G. \& BUSCH, S. 2010. Evaluation of different feed-in tariff design options - Best practice paper for the International Feed-in Cooperation. 3rd edition.

KPMG. 2014. Corporate tax rates table [Online]. KPMG International. Available: http://www.kpmg.com/global/en/services/tax/tax-tools-and-resources/pages/corporatetax-rates-table.aspx.

LÜTHI, S. \& WÜSTENHAGEN, R. 2012. The price of policy risk - Empirical insights from choice experiments with European photovoltaic project developers. Energy Economics, 34, 1001 1011.

MARON, H., KLEMISCH, H. \& MARON, B. 2011. Marktakteure Erneuerbare - Energien - Anlagen in der Stromerzeugung. Klaus Novy institut / trend:research.

MEDDE. 2013. Description du dispositif de soutien [Online]. Ministère de l'Ecologie, du Développement durable et de l'Energie Available: http://www.developpementdurable.gouv.fr/Quel-est-le-dispositif-de-soutien.html [Accessed 27 November 2013.

MENANTEAU, P., FINON, D. \& LAMY, M.-L. 2003. Prices versus quantities: choosing policies for promoting the development of renewable energy. Energy Policy, 31, 799-812.

MITCHELL, C., SAWIN, J. L., POKHAREL, G. R., KAMMEN, D., WANG, Z., FIFITA, S., JACCARD, M., LANGNISS, O., LUCAS, H., NADAI, A., BLANCO, R. T., USHER, E., VERBRUGGEN, A., WÜSTENHAGEN, R. \& YAMAGUCHI, K. 2011. Policy, Financing and Implementation. In: EDENHOFER, O., PICHS-MADRUGA, R., SOKONA, Y., SEYBOTH, K., MATSCHOSS, P., KADNER, S., ZWICKEL, T., EICKEMEIER, P., HANSEN, G., SCHLÖMER, S. \& VON STECHOW, C. (eds.) IPCC Special Report on Renewable Energy Sources and Climate change Mitigation. Cambridge, United Kingdom and New York, NY, USA: Cambridge University Press.

PHOTOVOLTAIK-GUIDE. 2013. Available: http://www.photovoltaik-guide.de/pv-preisindex.

PVGRID 2014. PV Grid Database. PV Grid Consortium.

REICHMUTH, M. 2011. Vorbereitung und Begleitung der Erstellung des Erfahrungsberichtes 2011 gemäß § 65 EEG - Endbericht Vorhaben II c Solare Strahlungsenergie. Leipziger Institut für Energie $\mathrm{GmbH}$.

REN21 2012. Renewables 2012 Global Status Report. (Paris: REN21 Secretariat). 